\title{
カラム実験より求められた土壤ガス中の 物質移動に関する物性値の妥当性評価
}

\author{
加納 由貴 ${ }^{1} \cdot$ 日比 義彦 ${ }^{2} \cdot$ 大平 雄毅 ${ }^{3}$ \\ 1名城大学大学院 理工学研究科環境創造学専攻（广468-8502 名古屋市天白区塩釜口1-501） \\ 2名城大学准教授 理工学部環境創造学科（干468-8502 名古屋市天白区塩釜口1-501） \\ E-mail: hibiy@meijo-u.ac.jp \\ 3 名城大学 理工学部環境創造学科（广468-8502 名古屋市天白区塩釜口1-501）
}

\begin{abstract}
土壤気相中の物質移動に関する物性值は, 屈曲度を考慮した分子拡散係数とKnudsen拡散係数および分 散長となる。 日比らは, 以前の研究でカラム実験結果よりこれらの物性值を求める手法を開発した。本研 究では, カラム実験より得られた物性值が妥当な值であるか確認寸るために二次元土槽実験と数值解析を 行った. 二次元土槽実験では, 物性值が得られている乾燥した豊浦砂または豊浦砂とベントナイトの混合 土と, 酸素と窒素を成分調整した混合ガスで満たされた土槽に二酸化炭素を注入した。 二次元土槽実験に 関する数值解析は, Dusty Gas Model を特性曲線型有限要素法で定式化した手法と, 以前の研究でカラム 実験より得られた物性值を用いて行われた。その結果，カラム実験で得られたこれらのパラメーターが適 切な值であることが分かった。
\end{abstract}

Key Words : dusty gasm model, molecular diffusion, Knudsen diffusion, tortuosity, dispersivity

\section{1. はじめに}

揮発性液体(塩素系有機溶剂，鉱物油等)による土㗧污 染では，土䁃ガス中の物質移動のメカニズムを把握する

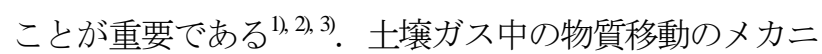
ズムは地下水中の物質移動よりも複雑となるにも関わら ず，土袞ガス中の物質移動にFickの法則がよく適用され

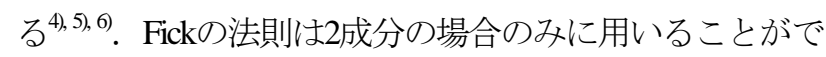
きるモデルである. しかし，実際の土壌ガス中では多成 分となるケースが多く, Fickの法則が適用できるケース は限られる．また，2成分の場合としても，Fickの法則 では，それぞれの分子量の違いによる非等モル流を表現 することができない，さらに，土粒子表面にガス成分の 分子が衝突して拡散するKnudsen拡散の影響もFickの法則 では考慮することができないか，89,90, 10, 11)。特に，透過度が $10^{-10} \mathrm{~cm}^{2}$ 以下となる場合には，Knudsen拡散を考慮できな いFickの法則では正確に流れの現象を再現できない、12). 一方，Dusty Gas モデルでは，多成分，非等モル流およ びKnudsen拡散を考慮することができ，ほぼすべての土 壤ガス中の物質移動の解析に適用可能である ${ }^{8}$.

Abu-Ei-Sha’r and Abriola ${ }^{13}$ は, ガスの流れのない状態で 行われたカラム実験結果から, Dusty Gasモデルを用いて 分子拡散に関する屈曲度, Knudsen拡散係数とKnudsen拡
散に関する屈曲度を求めた。 また, Hibi et al. ${ }^{14}$ は, Dusty Gasモデルの順解析結果を一次元移流分散方程式の理論 解にフィッテイングさせることにより非等モル流と Knudsen拡散の影響を受けた平均的な拡散係数を求めた. さらに，実験結果から得られた分散係数と平均的な拡散 係数を比較することで，屈曲度を考慮した分子拡散係数 と, Dusty Gasモデルを加味した機械的分散を求めた.

日比と田口 ${ }^{15}$ は一次元カラム装置を用いた実験結果と 二成分のDusty Gasモデルを用いて，土壤中の屈曲度を考 慮した分子拡散係数, 分子拡散に関係する屈曲度, 屈曲 度を考慮したKnudsen拡散係数, 機械的分散係数を同時 に求める手法を開発した，さらに，実験結果からこの手 法を用いて各パラメーターを求めることができることを 確認した. しかし，この手法では，一次元カラム装置と 一次元の逆解析を用いて物性值を求めるために, 求めた 值が適切であるか確認する必要がある. そこで, 本研究 では二次元土槽実験と数值解析を行い, 求められた上記 の物性值が二次元土壤ガス中の物質移動の問題に適用で きるか確認した．なお，数值解析には，土壤ガスの物質 移動の数值解析プログラムawnflowDGM (Simulator for airwater-NAPL three phase flow with Dusty Gas Model) ${ }^{16,17}$ を用い た. その結果, カラム実験により求められた物性值が, 二次元の土袞ガスの流れの問題についても適用できるこ 


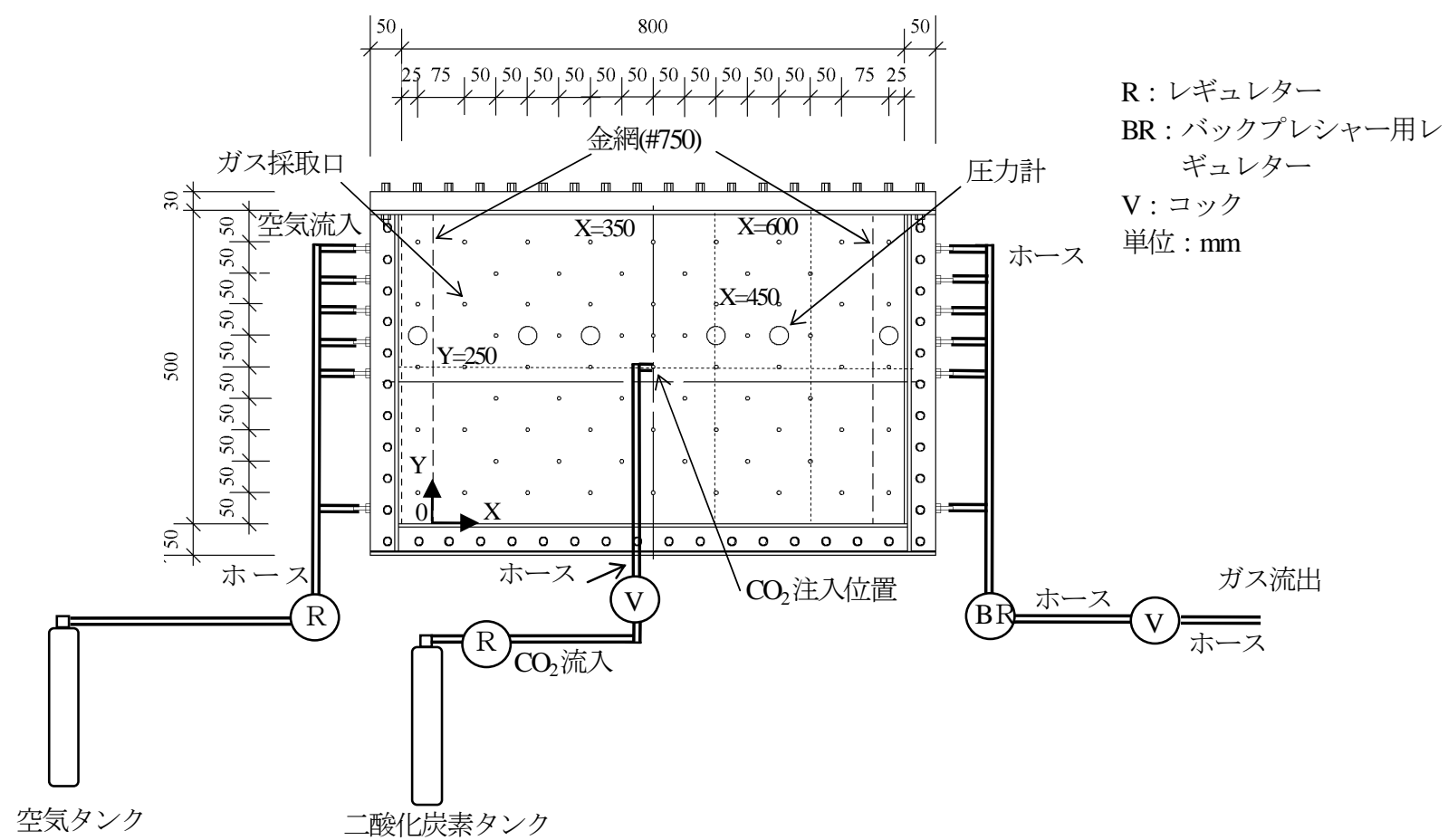

図-1 二次元土槽実験装置断面図（土槽縦 $500 \mathrm{~mm} \times$ 横 $800 \mathrm{~mm} \times$ 幅 $50 \mathrm{~mm}$ ）

とがわかった。

\section{2. 二次元土槽実験}

日比と田口 ${ }^{15)}$ が開発した手法により求められた土壌ガ ス中の屈曲度を考慮した分子拡散係数, 屈曲度を考慮し たKnudsen拡散係数と機械的分散係数の妥当性を判断す るために，図-1に示す土槽(縦500 mm,横800mm,幅50mm) を用いて二次元土槽実験を行った. 二次元土槽実験には, 日比と田口 ${ }^{15}$ が前記の物性值を求めた際に用いた乾燥し た豊浦砂(土粒子の密度 $2.65 \mathrm{~g} / \mathrm{cm}^{3}$ ) と, 豊浦砂とベントナ イト（株式会社ホージュン スーパークレイ土粒子密度 2.6g/ $\mathrm{cm}^{3}$ )の混合土(質量比 $4: 1$ )を用いた. また，バック グランドガスとして, 成分調整した混合ガス(ジャパン ファインダクツ株式会社 酸素 : 窒素=0.249: 0.751, 今後, この混合ガスを模擬空気と称す)と, 注入ガスとして高 純度の二酸化炭素(太陽日酸 規格G1 純度99.999)を用い た土槽実験を行った。なお，乾燥した土試料を用いたの で含水比は0\%である.

図-1に示すように，土槽正面の底から $300 \mathrm{~mm} の$ 高さの 位置に，土槽内のガス圧を測定するための電気式圧力計 (株式会社東京測器研究所PW-100kPa 最大測定圧力 $100 \mathrm{kPa}$ 最小目盛 $0.005 \mathrm{kPa}$ )を6力所設置し，ロガー(株式 会社東京測器研究所 TDS-303)により土槽内の圧力を自 動計測した。また，ガス採取口をX方向 $10 \mathrm{~cm} ， \mathrm{Y}$ 方向 5cmピッチでX方向に交互になるように70力所設置し, 採取口にはおねじコネクタ(株式会社コーヨー
RGM05818)にセプタム(HAMILTON 9mm DIA12/PK)を取り 付け，土槽正面に1/8インチネジで固定した。 ガスの採 取はガスシリンジ(SGE Analytical Science 最大目盛 $1.0 \mathrm{~mL}$ 最小目盛 $0.02 \mathrm{~mL})$ で行い，ガスクロマトグラフ(株式会社 ジェイサイエンスラボ GC7000T : 長楕円形コイル型ス テンレスカラム, 熱伝導型検出器, キャリアガス ヘリ ウム)により分析して, 各ガス成分の濃度をモル濃度で 求めた.

模擬空気は図-1の土槽左側の6箇所のホースニップル から土槽内一供給し，土槽右側の6力所のホースニップ ルからガスを排出した。入口には圧力調整器 (FAIRCHILD MODEL10 $0 \sim 15 \mathrm{kPa}$, 圧力計最大圧力 $5 \mathrm{kPa}$ 最小目盛 $0.1 \mathrm{kPa})$ と, 出口側にはバックプレッシャ一用圧 力調整器(FAIRCHILD MODEL 10BP $0 \sim 15 \mathrm{kPa}$, 圧力計 最大圧力 $5.0 \mathrm{kPa}$ 最小目盛 $0.1 \mathrm{kPa}$ )を取り付けることでガ ス圧を調整し，土槽左側から右側への模擬空気の流れを 土槽中に生じさせた.

土槽中央部(土槽下から $250 \mathrm{~mm}$ ，土槽左から $450 \mathrm{~mm}$ )に $\mathrm{CO}_{2}$ の注入口をとりつけ, 圧力調整器(FAIRCHILD MODEL10 $0 \sim 15 \mathrm{kPa}$, 圧力計 最大圧力 $5 \mathrm{kPa}$ 最小目盛 $0.1 \mathrm{kPa})$ により土槽内に $\mathrm{CO}_{2}$ を注入した.

最初に，日比と田口 ${ }^{15}$ が行ったカラム試験の間隙比と 同じになるように土質試料を図-1に示した金網間に詰め た。実際に試料を詰める際には，豊浦砂の場合には 2620g, 豊浦砂十ベントナイトの混合土の場合には2570g ずつ試料を自由落下させて詰め, 入れた試料厚が $5 \mathrm{~cm}$ と なるまで土槽周辺を打撃して試料を締め固めた．その結 果, 豊浦砂では間隙率が0.417 (日比と田口 ${ }^{15}$ )の場合 : 
0.428)，豊浦砂十ベントナイトでは間隙率が0.444(日比と 田口 ${ }^{15}$ の場合：0.433)となった。 なお，日比と田口 ${ }^{15}$ に よると，このように詰めた豊浦砂で全体の拡散のうち7 〜9\%がKnudsen拡散，豊浦砂+ベントナイトで 40～57\%程 度がKnudsen拡散の影響を受けていると考えられる. 従 って，豊浦砂の場合ではKnudsen拡散の影響をほとんど 受けないケースとなり，一方，豊浦砂+ベントナイトで はKnudsen拡散の影響を受けるケースとなる.

土質試料を詰め，装置からのガス漏れを点検した後， 注入・排出口に設置した圧力調整器を用いて，土槽内を 模擬空気で両たした。この際, 排出口側のコックは解放 させた状態とした. 装置内が模擬空気で満たされている かどうかは，土槽中央部および金網より $5 \mathrm{~cm}$ 内側のガス 採取口よりガスシリンジでガスを採取し，ガスクロマト グラフにて分析を行うことで確認した.

模擬空気で土槽内が満たされた後, $\mathrm{CO}_{2}$ 側の圧力を圧 力調整器により調整し， $\mathrm{CO}_{2}$ のコックを開放して $\mathrm{CO}_{2}$ を 土槽内に注入した。 $\mathrm{CO}_{2}$ を, 豊浦砂の場合で180秒間, 豊浦砂+ベントナイトの場合で1200秒間注入した後, ガ スシリンジにて土槽内のガスを採取し，ガスクロマトグ ラフにより分析を行った. ガスシリンジにて採集するガ スの量は0.15mlとし，ガスクロマトグラフにて分析を行 う際，シリンジの針部分の空気を追い出すために $0.05 \mathrm{ml}$

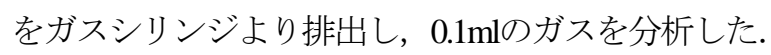

今回の実験では，土槽の模擬空気流入口と流出口の圧 力差が，豊浦砂の場合で $0.096 \mathrm{kPa} 0.216 \mathrm{kPa}$, 豊浦砂+べ ントナイトの場合で $0.473 \mathrm{kPa} と 0.878 \mathrm{kPa}$ でCO $\mathrm{CO}_{2}$ を注入した 土槽内のガス採取は, 豊浦砂の場合で $\mathrm{CO}_{2}$ 注入開始後 180 秒と 360 秒 $\left(\mathrm{CO}_{2}\right.$ 注入終了後 180 秒 $)$, 豊浦砂 + ベント ナイトの場合で $\mathrm{CO}_{2}$ 注入開始後20分と30分 $\left(\mathrm{CO}_{2}\right.$ 注入終 了後10分）で行われた．なお，ガス採取による土槽内の ガスの流れの乱れを生じさせないために, $\mathrm{CO}_{2}$ 注入時に ガスを採取する場合には， $\mathrm{CO}_{2}$ を注入した状態でガス採 取を行った時点で実験を終了した．さらに， $\mathrm{CO}_{2}$ 注入終 了後放置してガスを採取する場合には, $\mathrm{CO}_{2}$ の注入から 実験を再度行って， $\mathrm{CO}_{2}$ 注入終了後放置してガス採取を 行った.

これらの実験は18.6 20.6드の恒温室にて行われた。 な お，土槽内の全圧が解析に必要となるため，全圧は気圧 計により測定された気圧と圧力計により測定された圧力 の合計とした.

\section{3. 解析}

土壤ガスの流速はダルシーの法則に従うことがよく知 られている.もし，ガス滑りが生じないとすると，

$$
\mathbf{V}_{g}=-\frac{K_{r g} k_{s}}{\mu_{g}}\left(\nabla P_{g}+\rho_{g} g \nabla z\right)
$$

となる.ここで， $\mathbf{V}_{g}$ は土畩ガスのガス流速 $(\mathrm{L} / \mathrm{T}), K_{r g}$ は固有透過度に対するガスの相対透過度, $k_{s}$ は固有透 過度 $\left(\mathrm{L}^{2}\right), \mu_{g}$ は混合ガスの粘性係数( $(\mathrm{M} / \mathrm{LT}), P_{g}$ はガス の全圧 $\left(\mathrm{M} / \mathrm{LT}^{2}\right), \quad \rho_{g}$ はガス密度 $\left(\mathrm{M} / \mathrm{L}^{3}\right), \quad g$ は重力加速度 $\left(\mathrm{L} / \mathrm{T}^{2}\right), \mathrm{z}$ は上向きをプラスとした鉛直座標である.

ガスの流れの支配方程式はダルシーの法則と質量保存 の法則により，

$$
\frac{\partial \theta_{g}}{\partial t}=\nabla \cdot\left[\frac{K_{r g} k_{s}}{\mu_{g}}\left(\nabla P_{g}+\rho_{g} g \nabla z\right)\right]
$$

となる.ここで, $t$ は時間(T), $\theta_{g}$ 空隙率(無次元)であり， 空隙率とは土中に占めるガスの体積の比を示す.上記の 式(2)は，ガスの非压縮性の支配方程式となり，密度流 を考慮することができる.

また，土中の多成分の場合の分子拡散はDusty Gasモデ ルにより以下のように表される.

$$
\begin{array}{r}
\sum_{\substack{j=1 \\
j \neq i}}^{v} \frac{X_{i} \mathbf{N}_{j}^{D}-X_{j} \mathbf{N}_{i}^{D}}{\tau_{m} \theta_{g} D_{i j}}-\frac{\mathbf{N}_{i}^{D}}{\tau_{P} \theta_{g} D_{i}}=\frac{1}{R T} \nabla\left(P_{i}+\rho_{i} g z\right) \\
(i=1 \sim v)
\end{array}
$$

$X_{i}^{D}$ と $X_{j}^{D}$ は成分 $i$ と $j$ のモル分率, $\mathbf{N}_{i}^{D}$ と $\mathbf{N}_{j}^{D}$ は成 分 $i$ と $j$ の拡散による物質流束 $\left(\mathrm{mol} / \mathrm{L}^{2} \mathrm{~T}\right)$ であり， $\tau_{m}$ は分 子拡散に関する屈曲度(無次元)， $\tau_{P}$ はKnudsen拡散に関 する屈曲度, $D_{i j}$ は成分 $i$ と成分 $j$ 間の分子拡散係数 $\left(\mathrm{L}^{2} / \mathrm{T}\right), D_{i}$ は成分 $i$ の Knudsen拡散係数 $\left(\mathrm{L}^{2} / \mathrm{T}\right), \quad R$ はガス 定数 $\left(\mathrm{ML}^{2} / \mathrm{molKT}^{2}\right), T$ は温度 $(\mathrm{K}), P_{i}$ は成分 $i$ の分圧 $\left(\mathrm{M} / \mathrm{LT}^{2}\right), \rho_{i}$ は成分 $i$ の密度 $\left(\mathrm{M} / \mathrm{L}^{3}\right), v$ は土堙ガス中の成 分数である. また, 全モル流束 $\mathbf{N}_{i}^{T}$ については以下の式 により求めることができる.

$$
\begin{gathered}
\mathbf{N}_{i}^{T}=-\theta_{g} D_{c i j} \nabla C_{i}-\left[\frac{\theta_{g} M_{i} \mathbf{g} D_{c i j}}{R T}+\right. \\
\left(\frac{\theta_{g} D_{c i j}}{C R T} \sum_{j=1, j \neq i}^{v} \frac{\tau_{P} D_{j}}{\tau_{m} D_{i j}}+\frac{K_{r g} k_{s}}{\mu_{g}}\right) \nabla\left(P_{g}+\rho_{g} g z\right) \\
\left.+\frac{D_{c i j}}{C} \sum_{j=1, j \neq i}^{v} \frac{1}{\tau_{m} D_{i j}}\left(\sum_{k=1, k \neq i, k \neq j}^{v} \frac{D_{j}}{D_{k}} \mathbf{N}_{k}^{D}\right)\right] C_{i}
\end{gathered}
$$

ここで,

$$
D_{c i j}=\frac{1}{\sum_{\substack{j=1 \\ j \neq i}}^{v}\left(\frac{D_{j}}{D_{i}} \frac{X_{i}}{\tau_{m} D_{i j}}+\frac{X_{j}}{\tau_{m} D_{i j}}\right)+\frac{1}{\tau_{P} D_{i}}}
$$


表-1 解析に用いた試料とガスの物性值

\begin{tabular}{|c|c|c|c|}
\hline \multicolumn{2}{|l|}{ 料 } & 豊浦砂 & $\begin{array}{l}\text { 豊浦砂+ベン } \\
\text { トナイト }\end{array}$ \\
\hline \multicolumn{2}{|l|}{ 間 隙 } & $0.428{ }^{15}$ & 0.447 \\
\hline \multicolumn{2}{|l|}{ 透 過 度 } & $2.05 \times 10^{-11} \mathrm{~m}^{2}$ & $1.87 \times 10^{-12} \mathrm{~m}^{2}$ \\
\hline \multirow{2}{*}{ 分散長 ${ }^{15}$} & 縦方向 & $0.791 \mathrm{~cm}$ & $0.426 \mathrm{~cm}$ \\
\hline & 横方向 & $0.791 \mathrm{~cm}$ & $0.426 \mathrm{~cm}$ \\
\hline \multirow{2}{*}{ 気温 } & Case1 & $18.6^{\circ} \mathrm{C}$ & $20.0^{\circ} \mathrm{C}$ \\
\hline & Case2 & $18.6^{\circ} \mathrm{C}$ & $19.9^{\circ} \mathrm{C}$ \\
\hline \multirow{2}{*}{ 大気圧 } & Case1 & $102.4 \mathrm{kPa}$ & $101.8 \mathrm{kPa}$ \\
\hline & Case2 & $101.9 \mathrm{kPa}$ & $102.4 \mathrm{kPa}$ \\
\hline \multirow{3}{*}{ 粘性係数 ${ }^{19)}$} & $\mathrm{CO}_{2}$ & \multicolumn{2}{|c|}{$1.47 \times 10^{-5} \mathrm{~Pa} \cdot \mathrm{s}$} \\
\hline & $\mathrm{N}_{2}$ & \multicolumn{2}{|c|}{$1.76 \times 10^{5} \mathrm{~Pa} \cdot \mathrm{s}$} \\
\hline & $\mathrm{O}_{2}$ & \multicolumn{2}{|c|}{$2.04 \times 10^{5} \mathrm{~Pa} \cdot \mathrm{s}$} \\
\hline \multirow{3}{*}{ 分子量 } & $\mathrm{CO}_{2}$ & \multicolumn{2}{|c|}{$44.0 \mathrm{~g} / \mathrm{mol}$} \\
\hline & $\mathrm{N}_{2}$ & \multicolumn{2}{|c|}{$28.0 \mathrm{~g} / \mathrm{mol}$} \\
\hline & $\mathrm{O}_{2}$ & \multicolumn{2}{|c|}{$32.0 \mathrm{~g} / \mathrm{mol}$} \\
\hline \multirow{3}{*}{$\begin{array}{c}\text { 屈曲度を考慮した } \\
\text { 分子拡散係数 }\end{array}$} & $\mathrm{CO}_{2}-\mathrm{N}_{2}$ & $0.117 \mathrm{~cm}^{2} / \mathrm{s}$ & $0.130 \mathrm{~cm}^{2} / \mathrm{s}$ \\
\hline & $\mathrm{CO}_{2}-\mathrm{O}_{2}$ & $0.112 \mathrm{~cm}^{2} / \mathrm{s}$ & $0.128 \mathrm{~cm}^{2} / \mathrm{s}$ \\
\hline & $\mathrm{O}_{2}-\mathrm{N}_{2}$ & $0.155 \mathrm{~cm}^{2} / \mathrm{s}$ & $0.172 \mathrm{~cm}^{2} / \mathrm{s}$ \\
\hline \multirow{3}{*}{$\begin{array}{l}\text { 屈曲度を考慮した } \\
\text { Knudsen 拡散係数 }{ }^{15}\end{array}$} & $\mathrm{CO}_{2}$ & $1.12 \mathrm{~cm}^{2} / \mathrm{s}$ & $0.133 \mathrm{~cm}^{2} / \mathrm{s}$ \\
\hline & $\mathrm{N}_{2}$ & $1.80 \mathrm{~cm}^{2} / \mathrm{s}$ & $0.719 \mathrm{~cm}^{2} / \mathrm{s}$ \\
\hline & $\mathrm{O}_{2}$ & $1.80 \mathrm{~cm}^{2} / \mathrm{s}$ & $0.719 \mathrm{~cm}^{2} / \mathrm{s}$ \\
\hline
\end{tabular}

となり， $C_{i}$ は成分iのモル濃度 $\left(\mathrm{mol} / \mathrm{L}^{3}\right), M_{i}$ は成分iの分 子量 $(\mathrm{M} / \mathrm{mol}), C$ はガスの全体のモル濃度 $\left(\mathrm{mol} / \mathrm{L}^{3}\right)$ となる。 式(4)の右辺の第一項は, Knudsen拡散と分子拡散を含 む拡散項である. 右辺第2項は移流項となり, 重力, ガ スの流速, Knudsen拡散, 他成分の物質流束の影響が加 味されている.

ここで，上記の式(5)に機械的分散を考慮して質量保 存則の式に代入すると，以下の式(6)を得る.

$$
\frac{\partial C_{i}}{\partial t}+\mathbf{V}_{g i}^{*} \cdot \nabla C_{i}=\nabla \cdot\left(D_{i_{l n}}^{*} \nabla C_{i}\right)
$$

ここで， $D_{i l n}^{*}$ は以下の式(7)で表される.

$$
D_{i l n}^{*}=\delta_{l n} D_{c i j}+D_{\text {Mecha ln }}
$$

また，機械的分散係数 $D_{\text {Mechaln }}$ は以下の式(8)となり，

$$
D_{\text {Mechaln }}=\alpha_{T}\left|\mathbf{V}_{g}\right| \delta_{l n}+\left(\alpha_{L}-\alpha_{T}\right) \frac{V_{g_{l}} V_{g_{n}}}{\left|\mathbf{V}_{g}\right|}
$$

ここで， $\alpha_{L}$ は縦分散長(L)であり， $\alpha_{T}$ は横分散長 $(\mathrm{L})$ である、また， $V_{g_{l}}$ はl 方向の多孔体中のガスの流速で あり，下付の添え字 $l$ と $n$ は $x, y, z$ の座標を示し， $\left|\mathbf{V}_{g}\right|$ は速度のノムルである.さらに， $\delta_{l n}$ はクロネッカ 一のデルタである.

さらに， $\mathbf{V}_{g i}^{*}$ は以下の式で表される.

$$
\begin{gathered}
\mathbf{V}_{g i}^{*}=\frac{M_{i} g D_{c i j}}{R T}+\left(\frac{D_{c i j}}{C R T} \sum_{j=1, j \neq i}^{v} \frac{\tau_{p} D_{j}}{\tau_{m} D_{i j}}+\frac{K_{r g} k_{s}}{\theta_{g} \mu_{g}}\right) \nabla\left(P_{g}+\rho_{g} g z\right) \\
+\frac{D_{c i j}}{\theta_{g} C} \sum_{j=1, j \neq i}^{v} \frac{1}{\tau_{m} D_{i j}}\left(\sum_{k=1, k \neq i, k \neq j}^{v} \frac{D_{j}}{D_{k}} \mathbf{N}_{k}^{D}\right)
\end{gathered}
$$

式(6)では分子拡散，非等モル流，Knudsen拡散，屈曲 度および機械的分散を扱うことができるが，化学反応に よる影響および遅延効果などは考慮されていない，

Hibi et al. ${ }^{16}$ は，上記の式(6)を特性曲線型有限要素法 ${ }^{18)}$ で 定式化したawnflowDGM(Simulator for air - water - NAPL three phase flow with Dusty Gas Model ${ }^{16,17)}$ 開発した. この解析 プログラムを用いて，前記の土槽実験について数值解析 を行い，その数值解析結果と実験結果を比較することに

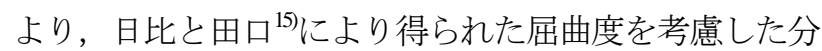
子拡散係数，屈曲度を考慮したKnudsen拡散係数と機械 的分散係数の妥当性を検討した.

今回の実験では，乾燥土を用いたので空隙率と間隙 比は等しくなり，解析では含水の影響を考慮しなかった また，解析に用いた試料およびガスの物性值を表-1に示 す. 表-1に示す豊浦砂の透過度は日比と田口 ${ }^{15)}$ が行った カラム実験より得られた值を用いた。一方，豊浦砂十べ ントナイトについては, 図-1に示寸二次元土槽の左側に 設置した加圧用圧力調整器と右側の背圧用圧力調整器に より土槽の左右でガスの圧力差を生じさせて，土槽の左 側から右側一一様なガスの流れを生じさせた．その際に, 土槽内のガス圧は圧力計により測定し，ガス流量は排出 口側に設置した流量計により測定した。 得られた土槽内 のガス圧とガス流量を用いて，豊浦砂+ベントナイトの 透気係数を求めた. 粘性係数及び分子拡散係数はPoling et al. ${ }^{19)}$ より引用した. さらに, 豊浦砂および豊浦砂+ベン トナイトの分子拡散係数に関する屈曲度, $\mathrm{CO}_{2}$ と $\mathrm{N}_{2}$ の屈 曲度を考慮したKnudsen拡散係数および分散長は, 日比 と田口 ${ }^{15}$ の実験で得られた值とした。 なお， $\mathrm{O}_{2}$ の屈曲度 を考慮したKnudsen拡散係数は分子量が近い $\mathrm{N}_{2}$ の值とし た.

解析領域は土槽内に土試料を詰めた横 $70 \mathrm{~cm} \times$ 縦 $50 \mathrm{~cm}$ の範囲とし，鉛直方向 $1 \mathrm{~cm} \times$ 水平方向 $1 \mathrm{~cm}$ の長方形要素 で解析領域を分割した(節点数3621, 要素数3500). 解析 領域の分割図と境界条件を豊浦砂については図-2に,

「豊浦砂十ベントナイト」については図-3に示す。

図-2および図-3に示すように，土槽の上下の境界はす べてのガス成分を通さない不透気境界とした．また，土 槽の両側の境界のガス圧を実験の際に土槽内で測定した ガス圧とした．さらに，土槽の左側の境界の濃度は，模 擬空気の成分（酸素と窒素の比 0.249:0.751）とし，土 槽の右側境界では，ガス流速の移流により土槽より各成 
Case1

\begin{tabular}{|c|}
\hline $0 \leq t \leq 180 \mathrm{~s}$ \\
$P_{\text {gas }}+\rho_{g} g \mathrm{z}=103.163 \mathrm{kPa}$ \\
$180<t \leq 360 \mathrm{~s}$ \\
$P_{\text {gas }}+\rho_{g} g \mathrm{z}=103.028 \mathrm{kPa}$ \\
$0<t \leq 360 \mathrm{~s}$ \\
$C_{\mathrm{CO} 2}=0.0 \mathrm{~mol} / \mathrm{m}^{3}$ \\
$C_{O 2}=0.249 P_{\text {gas }} / R T$ \\
$C_{N 2}=0.751 P_{\text {gas }} / R T$ \\
Case2 \\
$0 \leq t \leq 180 \mathrm{~s}$ \\
$P_{\text {gas }}+\rho_{g} g z=104.146 \mathrm{kPa}$ \\
$180<t \leq 360 \mathrm{~s}$ \\
$P_{\text {gas }}+\rho_{g} g \mathrm{~g}=104.113 \mathrm{kPa}$ \\
$0<t \leq 360 \mathrm{~s}$ \\
$C_{\mathrm{CO} 2}=0.0 \mathrm{~mol} / \mathrm{m}^{3}$ \\
$C_{O 2}=0.249 P_{\text {gas }} / R T$ \\
$C_{N 2}=0.751 P_{\text {gas }} / R T$
\end{tabular}

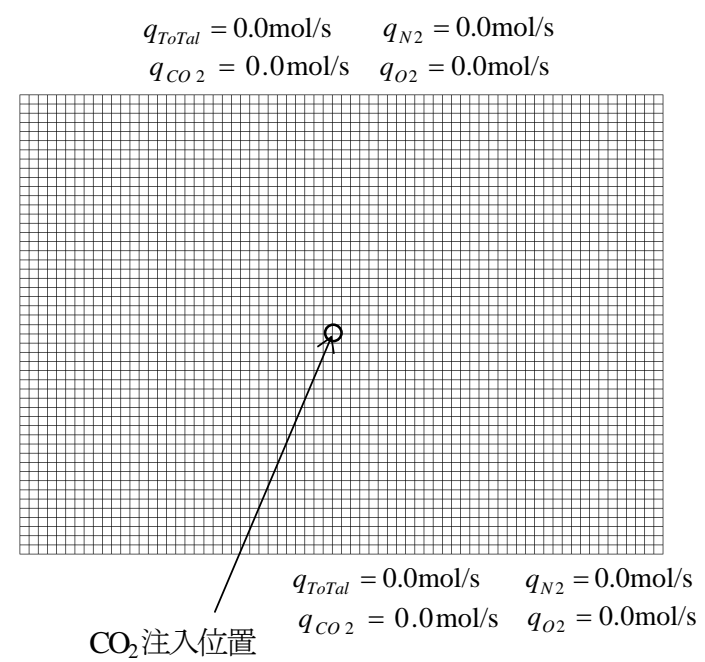

Case1

\begin{tabular}{|c|}
$0 \leq t \leq 180 \mathrm{~s}$ \\
$P_{g a s}+\rho_{g} g z=102.987 \mathrm{kPa}$ \\
$180<t \leq 360 \mathrm{~s}$ \\
$P_{\text {gas }}+\rho_{g} g \mathrm{z}=102.911 \mathrm{kPa}$ \\
$0<t \leq 360 \mathrm{~s}$ \\
$q_{\mathrm{CO} 2}=q_{\text {Total }} C_{\mathrm{CO} 2}$ \\
$q_{N 2}=q_{\text {Total }} C_{N 2}$ \\
$q_{O 2}=q_{\text {Total }} C_{O 2}$ \\
\hline
\end{tabular}

Case2

$0 \leq t \leq 180 \mathrm{~s}$

$P_{g a s}+\rho_{g} g z=103.907 \mathrm{kPa}$

$180<t \leq 360 s$

$P_{\text {gas }}+\rho_{g} g z=103.817 \mathrm{kPa}$

$0<t \leq 360$ s

$q_{\mathrm{CO} 2}=q_{\mathrm{Total}} C_{\mathrm{CO} 2}$

$q_{N 2}=q_{\text {Total }} C_{N 2}$

$q_{\mathrm{O} 2}=q_{\text {Total }} C_{\mathrm{O} 2}$

$\mathrm{CO}_{2}$ 注入位置境界条件

\begin{tabular}{|c|c|c|c|}
\hline \multicolumn{2}{|l|}{ Case1 } & \multicolumn{2}{|l|}{ Case2 } \\
\hline $0 \leq t \leq 180 \mathrm{~s}$ & $q_{N 2}=0.0 \mathrm{~mol} / \mathrm{s}$ & $0 \leq t \leq 180 \mathrm{~s}$ & $q_{12}=0.0 \mathrm{~mol} / \mathrm{s}$ \\
\hline $\begin{aligned} P_{\text {Total }} & =103.106 \mathrm{kPa} \\
C & =P\end{aligned}$ & $q_{O 2}=0.0 \mathrm{~mol} / \mathrm{s}$ & $\begin{aligned} P_{\text {Total }} & =104.056 \mathrm{kPa} \\
C & =P / R T\end{aligned}$ & $q_{N 2}=0.0 \mathrm{~mol} / \mathrm{s}$ \\
\hline $180<t \leq 360 s$ & & $180<t \leq 360 \mathrm{~s}$ & \\
\hline$q_{\text {ToTal }}=0.0 \mathrm{~mol} / \mathrm{s}$ & $q_{N 2}=0.0 \mathrm{~mol} / \mathrm{s}$ & $q_{\text {ToTal }}=0.0 \mathrm{~mol} / \mathrm{s}$ & $q_{N 2}=0.0 \mathrm{~mol} / \mathrm{s}$ \\
\hline$q_{\mathrm{CO} 2}=0.0 \mathrm{~mol} / \mathrm{s}$ & $q_{O 2}=0.0 \mathrm{~mol} / \mathrm{s}$ & $q_{\mathrm{CO} 2}=0.0 \mathrm{~mol} / \mathrm{s}$ & $q_{O 2}=0.0 \mathrm{~mol} / \mathrm{s}$ \\
\hline
\end{tabular}

$t$ : 時間 $q_{\text {Total }}$ : ガスの流量 $P_{g a s}$ : ガスの全圧 $C_{C O 2}$ : 二酸化炭素のモル濃度 $q_{O 2}$ : 酸素の流量 $q_{N 2}:$ 窒素の流量 $q_{\mathrm{CO} 2}$ : 二酸化炭素の流量 $C_{\mathrm{O} 2}$ : 酸素のモル濃度 $C_{N 2}$ : 窒素のモル濃度 $\rho_{g}$ : ガスの密度 $T$ : 絶対温度 $R:$ ガス定数 $g$ : 重力加速

\section{図-2 要素分割と境界条件（豊浦砂）}

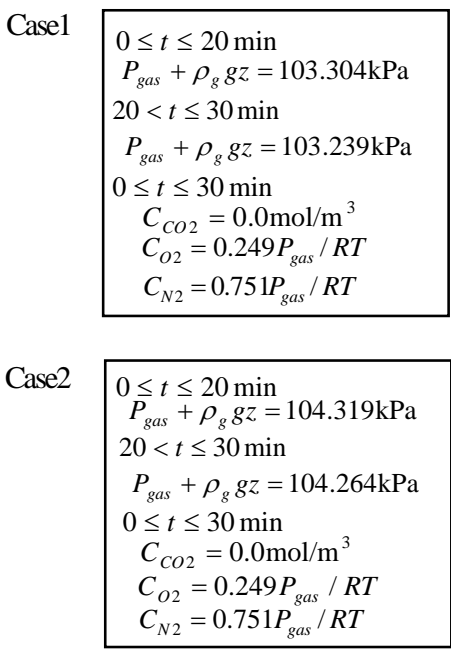
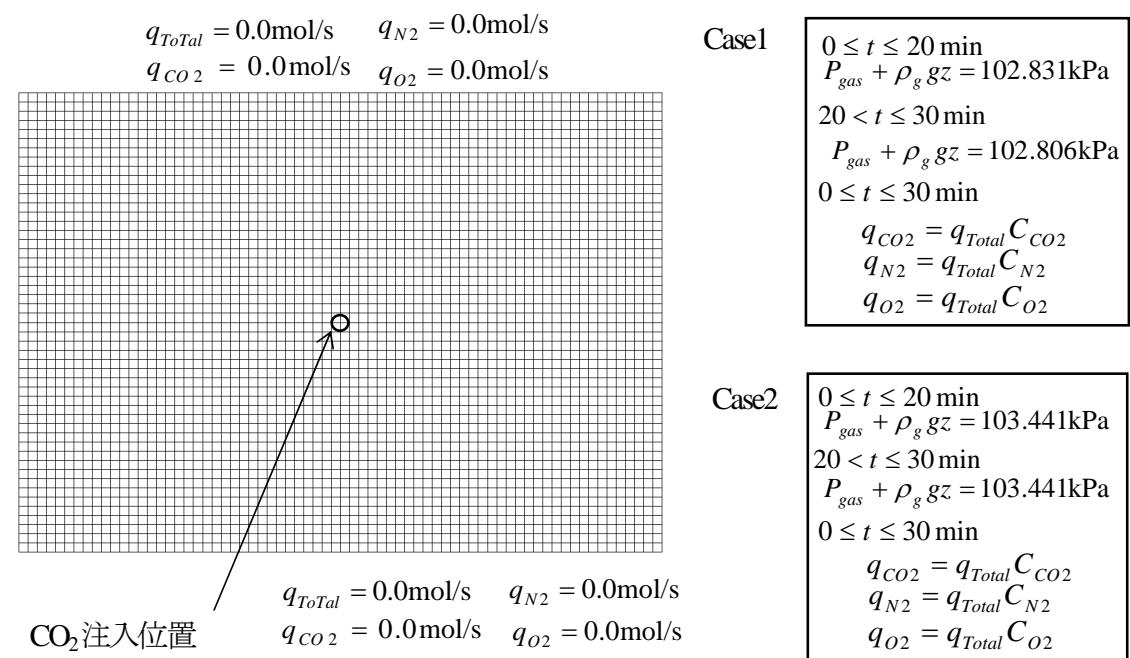

Case2

\begin{tabular}{|l|}
\hline $0 \leq t \leq 20 \mathrm{~min}$ \\
$P_{\text {gas }}+\rho_{g} g z=103.441 \mathrm{kPa}$ \\
$20<t \leq 30 \mathrm{~min}$ \\
$P_{\text {gas }}+\rho_{g} g z=103.441 \mathrm{kPa}$ \\
$0 \leq t \leq 30 \mathrm{~min}$ \\
$q_{\mathrm{CO2} 2}=q_{\text {Total }} C_{C O 2}$ \\
$q_{N 2}=q_{\text {Total }} C_{N 2}$ \\
$q_{O 2}=q_{\text {Total }} C_{O 2}$ \\
\hline
\end{tabular}

$\mathrm{CO}_{2}$ 注入位置境界条件

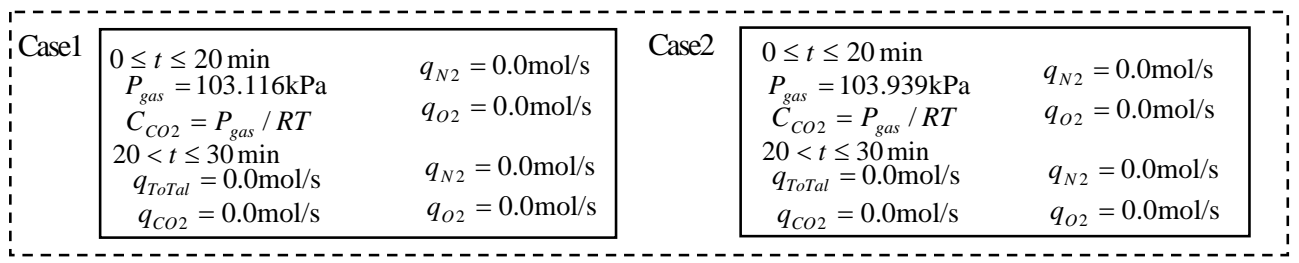

$t$ : 時間 $q_{\text {Total }}$ : ガスの流量 $P_{g a s}$ : ガスの全圧 $C_{C O 2}$ : 二酸化炭素のモル濃度 $q_{O 2}$ : 酸素の流量 $q_{N 2}:$ 窒素の流量 $q_{\mathrm{CO} 2}$ : 二酸化炭素の流量 $C_{O 2}$ : 酸素のモル濃度 $C_{N 2}$ : 窒素のモル濃度 $\rho_{g}$ : ガスの密度 $T$ : 絶対温度 $R:$ ガス定数 $g:$ 重力加速

図-3＼cjkstart要素分割と境界条件（豊浦砂十ベントナイト） 


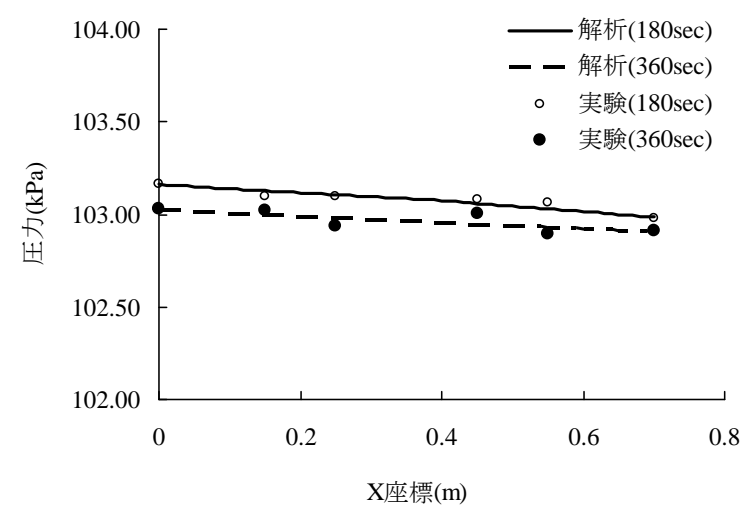

(a) 豊浦砂，圧力差 $0.096 \mathrm{kPa}$

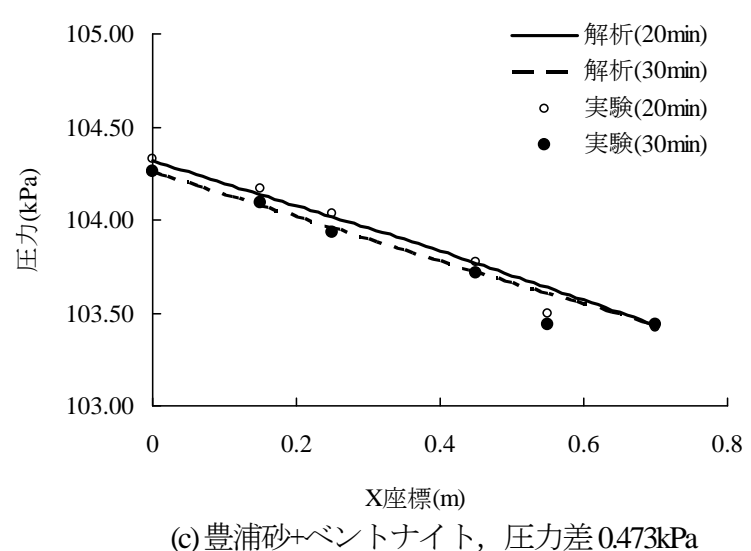

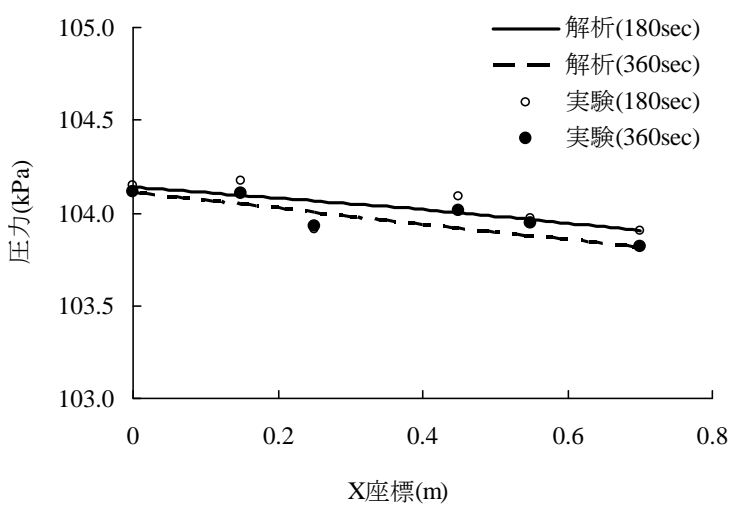

(b) 豊浦砂, 圧力差 $0.216 \mathrm{kPa}$

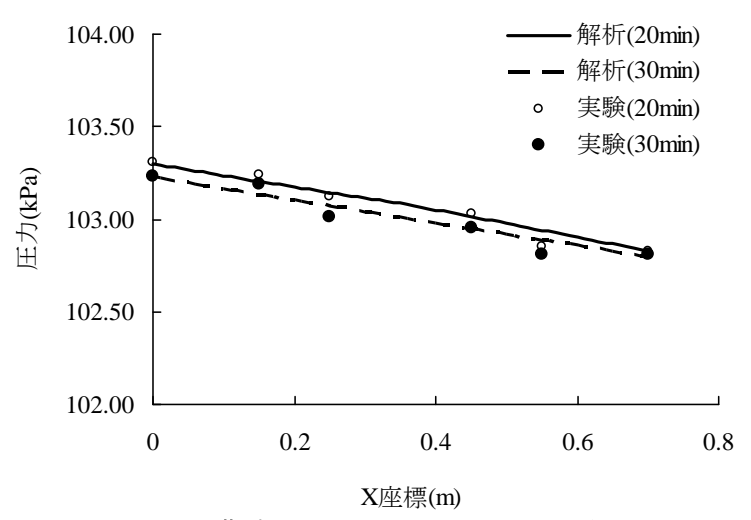

(d) 豊浦砂+ベントナイト，圧力差 $0.878 \mathrm{kPa}$

図-4 $\mathrm{Y}=30 \mathrm{~cm}$ における実験結果のガス圧力と解析結果のガスの圧力水頭の比較

分が排出されるようした．実際の解析では，土槽左側の 境界の酸素と窒素の濃度は, 測定されたガス圧と気体の 状態方程式により全モル濃度を算出し, 算出した全モル 濃度に前記の酸素と窒素の成分比を乗じて求められた. ただし，土槽左側の境界における $\mathrm{CO}_{2}$ の濃度は $0 \mathrm{~mol} / \mathrm{m}^{3}$ と した。一方，土槽右側の境界では，解析結果より得られ たガスの流量に計算結果より得られた各成分の濃度を乗 じて境界から流出する各成分の流量を算出し，各成分の 濃度が収束するまで計算を繰り返した． $\mathrm{CO}_{2}$ 注入位置で は，実験の際に土槽内で測定した圧力分布に概ね等しく なるように注入位置のガス圧を調節した。 この際のCO 注入位置の $\mathrm{CO}_{2}$ の濃度は，豊浦砂の場合で $\mathrm{CO}_{2}$ 注入開始 後180秒(図-2参照) または豊浦砂+ベントナイトの場合で $\mathrm{CO}_{2}$ 注入開始後 20 分（図-3参照）までは, $\mathrm{CO}_{2}$ の注入位置 のガス圧と気体の状態方程式から得られた全モル濃度と し，酸素および窒素の流入・流出はないものとした。 ま た，豊浦砂の場合で180秒以降(図-2参照)または豊浦砂+ ベントナイトの場合で20分以降(図-3参照)では，注入位 置からの $\mathrm{CO}_{2}$, 酸素および窒素の流入または流出がない ものとした.

図-4には解析結果と実験結果の $\mathrm{CO}_{2}$ 注入時及び実験終 了時の土槽内のガス圧の分布を示す. 前記したように, 実験で測定した土槽内のガス圧力の分布にフィッテイン
グするように数值解析におけるガス注入口のガス圧を調 整した。 その結果, 図-4に示寸ように, 実験結果の土槽 内のガス圧の分布と数值解析より得られたガス圧の分布 がほぼ同じような值になった。

\section{4. 実験結果と解析結果の比較}

図-5(a)と(b)には，試料が豊浦砂で，土槽の模擬空気の 流入口と流出口のガスの圧力差が $0.096 \mathrm{kPa}$ 場合の実験 より得られた実験開始後 180 秒後と 360 秒後の $\mathrm{CO}_{2}$ のモル 濃度分布と数值解析より得られたモル濃度分布を示寸。 また，図-5(c)と(d)には，ガスの圧力差0.216kPaの場合の 実験開始後180秒後と 360 秒後の実験および数值解析より 得られた $\mathrm{CO}_{2}$ の濃度分布を示す。

図-5(a)に示すように，ガスの圧力差が0.096kPaの場合 の $\mathrm{CO}_{2}$ の注入時（実験開始後180秒）における実験結果 と数值解析結果の比較によると $\mathrm{CO}_{2}$ の濃度 $2 \mathrm{~mol} / \mathrm{m}^{3}$ の分布 範囲は実駼結果と解析結果で一致した．また，図-5(b)で 示すように, $\mathrm{CO}_{2}$ 注入終了後180秒（実験開始後 360 秒) における実験結果と数值解析結果の $\mathrm{CO}_{2}$ の濃度 $2 \mathrm{~mol} / \mathrm{m}^{3} の$ 分布は，土槽排出口付近の部分以外では一致したが，土 槽排出口付近では実験結果の $\mathrm{CO}_{2}$ の濃度 $2 \mathrm{~mol} / \mathrm{m}^{3}$ の分布と 


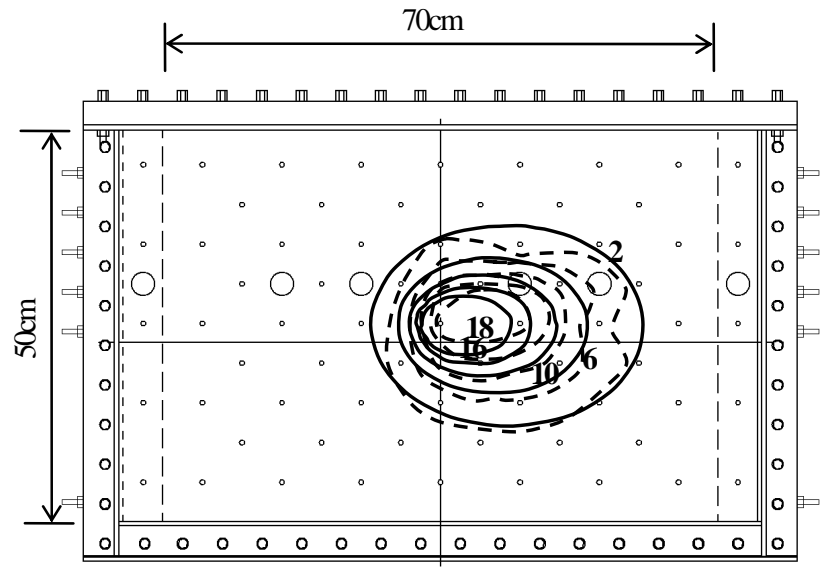

(a) 圧力差 $0.096 \mathrm{kPa}$ 経過時間 180 秒

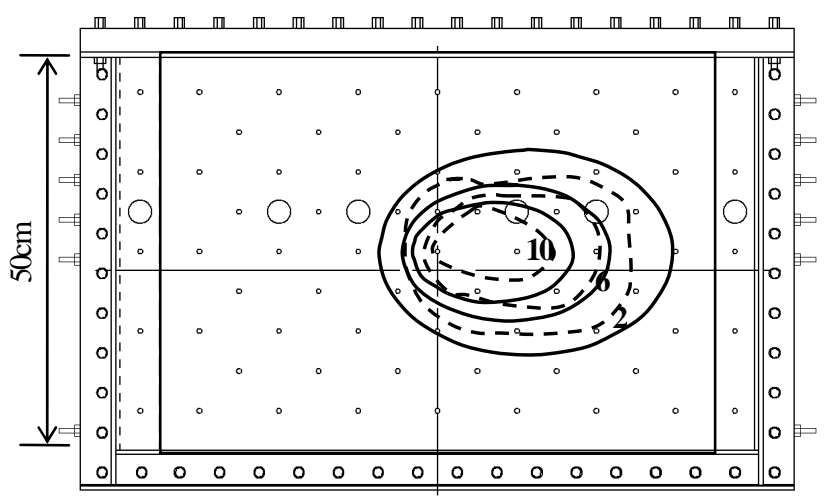

(c) 圧力差 $0.216 \mathrm{kPa}$ 経過時間 180 秒

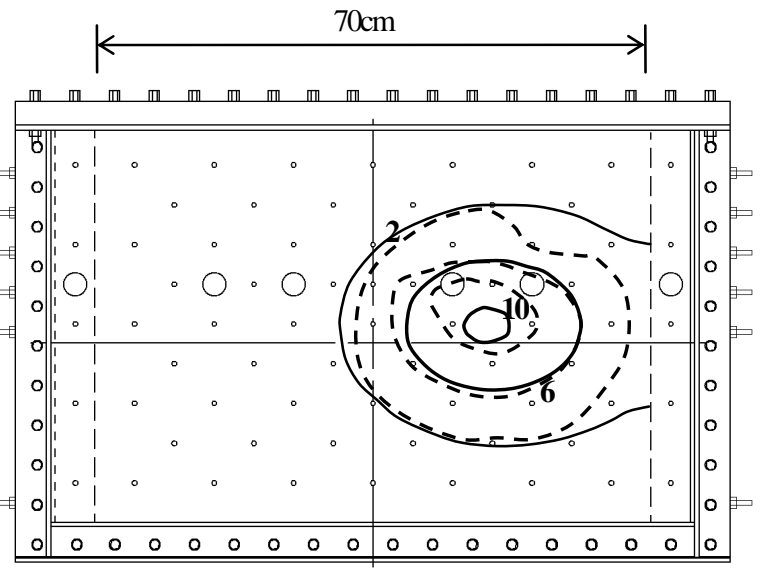

(b) 圧力差 $0.096 \mathrm{kPa}$ 経過時間 360 秒

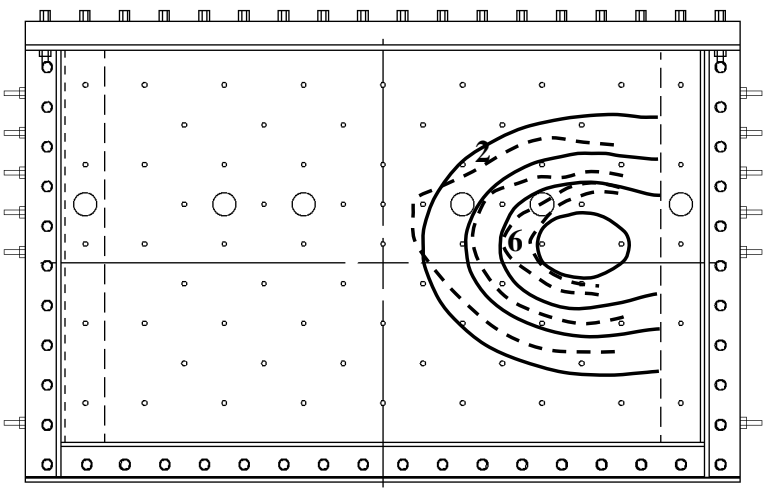

(d) 圧力差 $0.216 \mathrm{kPa}$ 経過時間 360 秒

- - - - 実験結果 — 解析結果 単位 : $\mathrm{mol} / \mathrm{m}^{3}$
解析結果の $2 \mathrm{~mol} / \mathrm{m}^{3}$ の分布に差が生じた. また，図-5(c)に よると，圧力差を $0.216 \mathrm{kPa}$ とした場合の $\mathrm{CO}_{2}$ 注入時（実 験開始後 180 秒）の数值解析結果の $\mathrm{CO}_{2}$ のモル濃度 $2 \mathrm{~mol} / \mathrm{m}^{3}$ の分布は，実験結果の範囲よりも広くなった。 また, 土槽排出口付近では解析結果と実験結果の分布範 囲の差がさらに大きくなる傾向となった．図-5(d)に示す ように, 同じ圧力差で $\mathrm{CO}_{2}$ 注入終了後 180 秒（実験開始 後360秒）の数值解析結果の $\mathrm{CO}_{2}$ のモル濃度 $2 \mathrm{~mol} / \mathrm{m}^{3}$ の分 布は，土槽排出口付近で実験結果の範囲より広くなった 以上のように, 豊浦砂の場合の実験結果と解析結果の $\mathrm{CO}_{2}$ の濃度 $2 \mathrm{~mol} / \mathrm{m}^{3}$ の分布範囲を比較すると風下側では解 析結果の範囲は実験結果の範囲より広くなる傾向が生じ た. 数值解析では土槽排出口の境界で解析領域から排出 されるガス流量にその境界の濃度を乗じて算出した流量 を境界の $\mathrm{CO}_{2}$ の流量とした。この境界の流量が実験結果 の流量より過剩であったことが原因であると考えられる。 特に, 豊浦砂における圧力差0.096kPaの場合にこの傾 向が顕著に生じたと考えられる.

図-6(a)と(b)には，試料が豊浦砂+ベントナイトで，模 擬空気の流入口と排出口のガスの圧力差が0.473kPaにお
ける $\mathrm{CO}_{2}$ 注入時（実験開始後20分）と $\mathrm{CO}_{2}$ 注入終了後 10 分（実験開始後30分）の実験結果と数值解析結果の $\mathrm{CO}_{2}$ のモル濃度分布を示す。また，図-6(c) と(d)には，模擬空 気のガスの圧力差 $0.878 \mathrm{kPa}$ 場合の $\mathrm{CO}_{2}$ 注入時（実験開 始後20分）と $\mathrm{CO}_{2}$ 注入終了後10分（実験開始後30分）の 実験結果と数值解析結果の $\mathrm{CO}_{2}$ のル濃度分布を示す. ガスの圧力差が $0.473 \mathrm{kPa} の \mathrm{CO}_{2}$ 注入時（実験開始後20分） では，図-6(a)に示すように，風上側では数值解析結果の $\mathrm{CO}_{2}$ の濃度 $2 \mathrm{~mol} / \mathrm{m}^{3}$ の分布範囲は実験結果の範囲と一致す るが，風下側の土槽排出口付近では数值解析結果の分布 範囲は実験結果より広くなった. また，図-6(b)に示すよ うに, $\mathrm{CO}_{2}$ 注入終了後 10 分（実験開始後30分）の解析結 果の $\mathrm{CO}_{2}$ の濃度 $2 \mathrm{mo} / \mathrm{m}^{3}$ の分布範囲は, 風上側で実験結果 の濃度 $2 \mathrm{~mol} / \mathrm{m}^{3}$ の分布位置と一致するが, $\mathrm{CO}_{2}$ の分布範囲 の上下では解析結果よりも実験結果の分布範囲が広くな った。また，図-6(c)に示すように，ガスの圧力差 $0.878 \mathrm{kPa}$ 場合については, $\mathrm{CO}_{2}$ 注入時（実験開始後 20 分）に，風上側および土槽の上下で数值解析結果の $\mathrm{CO}_{2}$ の濃度 $2 \mathrm{~mol} / \mathrm{m}^{3}$ の分布位置は実験結果の分布位置と一致 するが，土槽左側の排出口では，実験結果の $\mathrm{CO}_{2}$ の濃度 


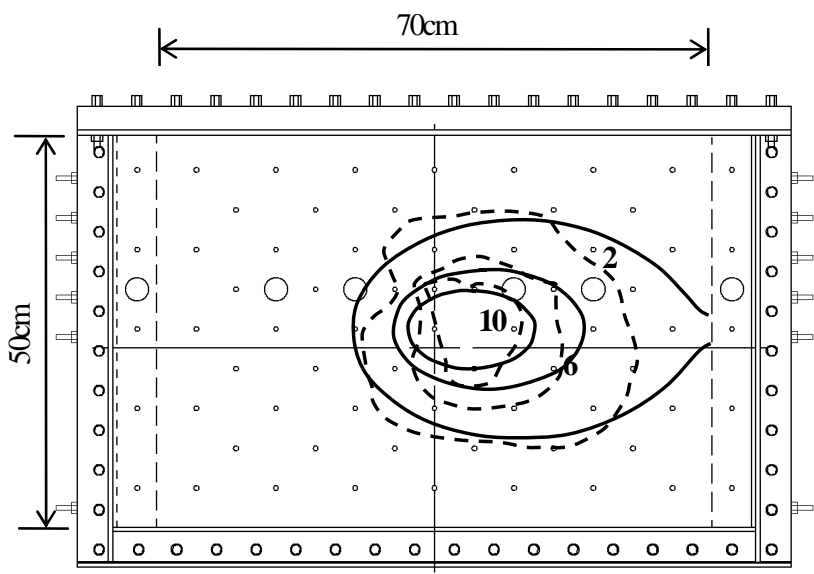

(a) 圧力差 $0.473 \mathrm{kPa}$ 経過時間 20 分

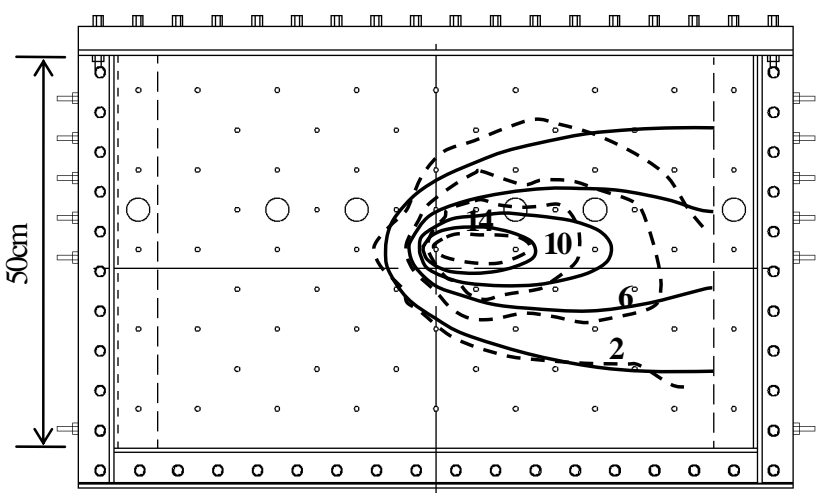

(c) 圧力差 $0.878 \mathrm{kPa}$ 経過時間 20 分

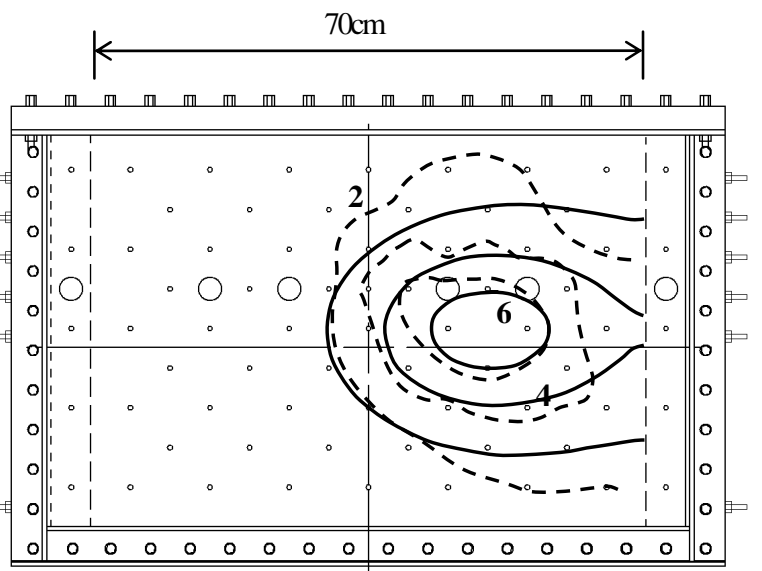

(b) 圧力差 $0.473 \mathrm{kPa}$ 経過時間 30 分

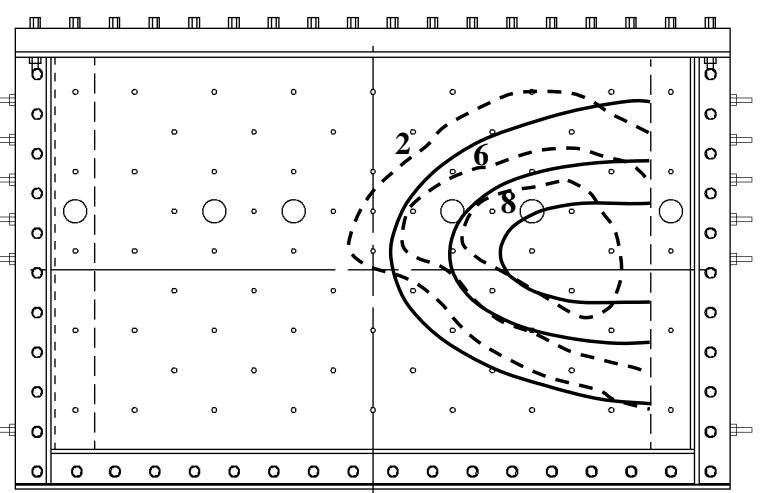

(d) 圧力差 $0.878 \mathrm{kPa}$ 経過時間 30 分

- - _ - 実験結果

(豊浦砂+ベントナイト)
解析結果

単位 : $\mathrm{mol} / \mathrm{m}^{3}$
$2 \mathrm{~mol} / \mathrm{m}^{3}$ の分布位置が解析結果の分布位置より土槽の下 方側に移動した. さらに, 図-6(d)に示すように, 圧力差 が0.878kPa $の \mathrm{CO}_{2}$ 注入終了後 10 分（実験開始後 30 分）の実 験結果と数值解析結果の $\mathrm{CO}_{2}$ のル濃度の分布は, 土槽 の上側の境界付近と土槽排出口付近でずれが生じた.

図-6(b)と(d)によると, 注入終了後10分における数值解析 結果の $\mathrm{CO}_{2}$ のモル濃度 $2 \mathrm{~mol} / \mathrm{m}^{3}$ の分布位置は，風下側また は土槽の上下方側で実験結果とずれ，実験結果の $\mathrm{CO}_{2}$ の モル濃度 $2 \mathrm{~mol} / \mathrm{m}^{3}$ の分布位置は上下対称とならずに土槽 の上方向側に移動する傾向があった. 一方，数值解析結 果では，その傾向を示さずに， $\mathrm{CO}_{2}$ 注入位置から上方向 及び下方向の $\mathrm{CO}_{2}$ のル濃度の分布範囲は対称となった 以上のことより, 豊浦砂+ベントナイトの場合では, 豊 浦砂の場合と同様に土槽排出口側の境界において，実験 の際に流れに乱れが生じ，実験結果の $\mathrm{CO}_{2}$ のル濃度の 分布が土槽の上下方向に移動した。一方，豊浦砂+ベン トナイトの場合でも数值解析の土槽排出口側の境界に $\mathrm{CO}_{2}$ の到達が早く, 数值解析において土槽排出口側の境 界条件を適切に設定できなかった可能性がある。しかし 図-5と図-6では，数值解析結果と実験結果の比較を定量 的に評価をすることが難しいので，図-7〜図-12に各断
面における濃度分布図を示した。

図-7と図-8には，豊浦砂で，模擬空気の流入口と流出 口のガスの圧力差が0.096kPaおよび0.216kPaの場合の $\mathrm{CO}_{2}$ 注入位置の高さとなる $\mathrm{Y}=25 \mathrm{~cm}$ の土槽横方向の $\mathrm{CO}_{2}, \mathrm{O}_{2}$ お よび $\mathrm{N}_{2}$ のモル濃度の分布をそれぞれ示寸，模擬空気の流 入口と流出口のガスの圧力差が0.096kPaの場合における 土槽右側の実験結果と数值解析結果の $\mathrm{CO}_{2}$ モル濃度の差 は，図-7によると最大 $2 \mathrm{~mol} / \mathrm{m}^{3}$ なった。一方，ガスの圧力 差0.216kPaの場合の実験結果と解析結果のCO 2 濃度の差 は図-8によると $\mathrm{X}=45 \mathrm{~cm} の 5 \mathrm{~mol} / \mathrm{m}^{3}$ となった。また，図-7 と図-8によると, $\mathrm{CO}_{2}$ 注入時（実験開始後 180 秒）におけ る解析結果と実駼結果の $\mathrm{CO}_{2}$ の濃度差は, $\mathrm{CO}_{2}$ 注入終了 後180秒（実験開始後360秒）における差よりも大きくな った. なお, 数值解析結果と実験結果の $\mathrm{CO}_{2}$ のル濃度 の差が大きい籄所については, 同様に数值解析結果と実 験結果の $\mathrm{N}_{2}$ のル濃度の差が生じていることが分かった。

図-9 と図-10にCO 2 注入位置の高さ $(\mathrm{Y}=25 \mathrm{~cm}) の \mathrm{CO}_{2}, \mathrm{O}_{2}$ および $\mathrm{N}_{2}$ のモル濃度分布を示寸， 図-9によると，豊浦砂 +ベントナイト, 模擬空気の流入口と流出口のガスの圧 力差が $0.473 \mathrm{kPa}$ 場合では, 数值解析結果の $\mathrm{CO}_{2}$ 濃度が 実験結果の $\mathrm{CO}_{2}$ 濃度より $2 \mathrm{~mol} / \mathrm{m}^{3}$ 大きくなり, 図-10によ 


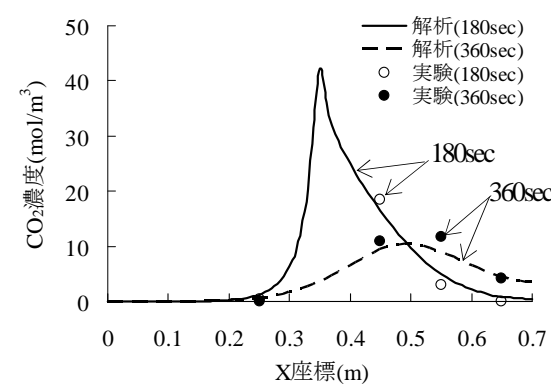

(a) $\mathrm{CO}_{2}$

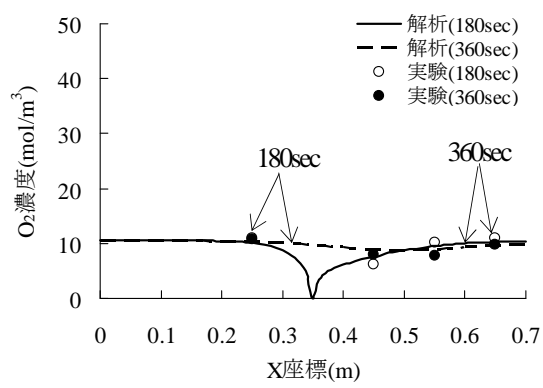

(b) $\mathrm{O}_{2}$

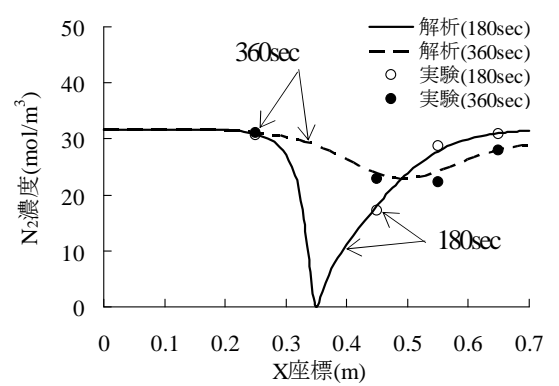

(c) $\mathrm{N}_{2}$

図-7 $\mathrm{Y}=25 \mathrm{~cm}$ における各成分の濃度分布（豊浦砂，圧力差 $0.096 \mathrm{kPa}$ ）

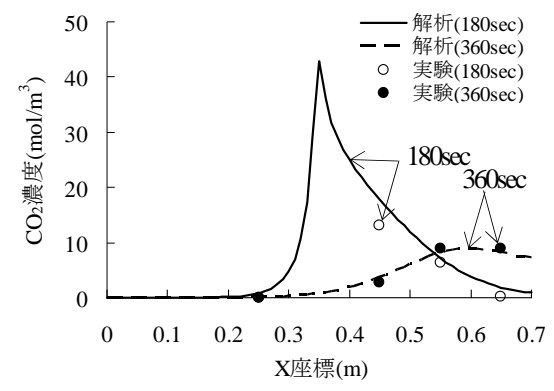

(a) $\mathrm{CO}_{2}$

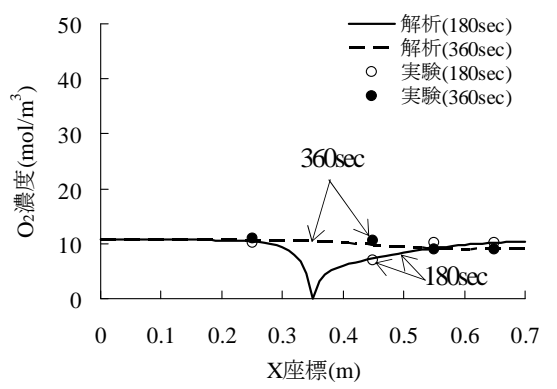

(b) $\mathrm{O}_{2}$

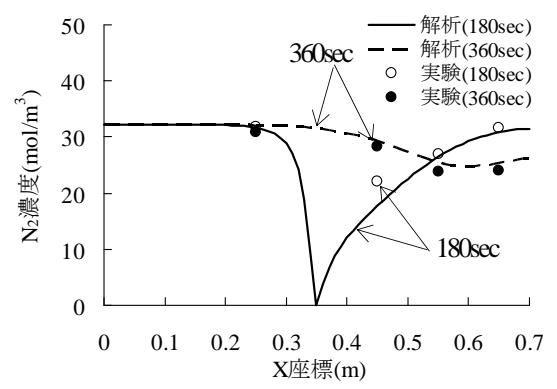

(c) $\mathrm{N}_{2}$

図-8 $\mathrm{Y}=25 \mathrm{~cm}$ における各成分の濃度分布（豊浦砂，圧力差 $0.216 \mathrm{kPa}$ )

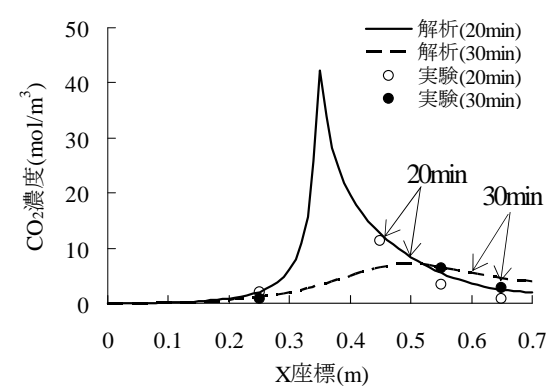

(a) $\mathrm{CO}_{2}$

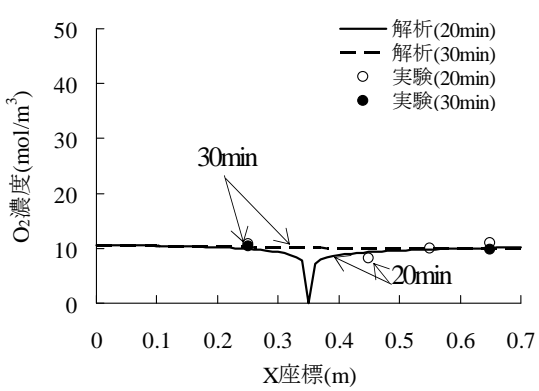

(b) $\mathrm{O}_{2}$

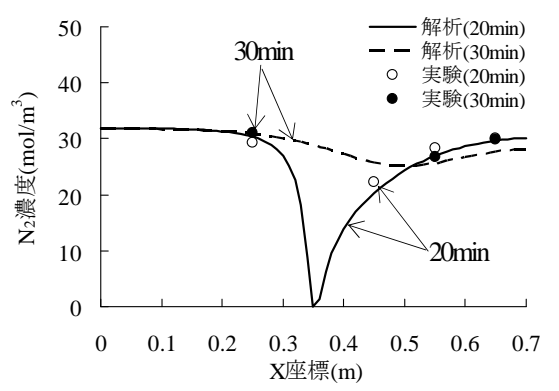

(c) $\mathrm{N}_{2}$

図-9 Y=25cmにおける各成分の濃度分布（豊浦砂+ベントナイト, 圧力差 $0.473 \mathrm{kPa}$ )

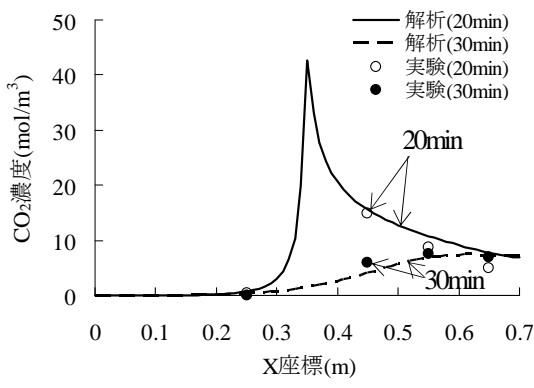

(a) $\mathrm{CO}_{2}$

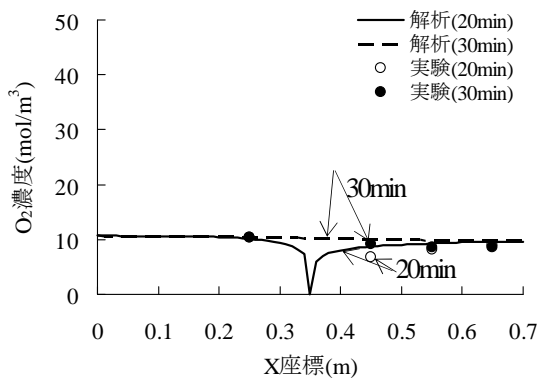

(b) $\mathrm{O}_{2}$

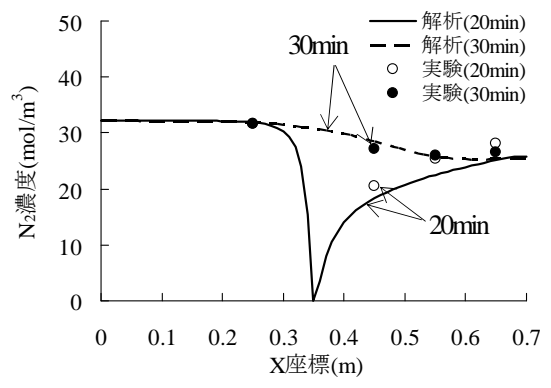

(c) $\mathrm{N}_{2}$

図-10 Y=25cmにおける各成分の濃度分布（豊浦砂+ベントナイト，圧力差 $0.878 \mathrm{kPa}$ ）

ると，圧力差 $0.878 \mathrm{kPa}$ 場合では数值解析結果の $\mathrm{CO}_{2}$ 濃 度が実験結果の $\mathrm{CO}_{2}$ 濃度より最大 $3 \mathrm{~mol} / \mathrm{m}^{3}$ 大きくなった.

また，図-11と図-12には，実験および数值解析より求 めた豊浦砂+ベントナイトの場合の土槽の縦方向の $\mathrm{CO}_{2}$, $\mathrm{O}_{2}$ および $\mathrm{N}_{2}$ のモル濃度の分布を示す. 図-11によると, $\mathrm{X}=35 \mathrm{~cm}$ の位置では, 数值解析結果の $\mathrm{CO}_{2}$ のモル濃度は実
験結果の $\mathrm{CO}_{2}$ のモル濃度より最大 $6 \mathrm{~mol} / \mathrm{m}^{3}$ 小さくなり， 図-6に示す傾向と同様に土槽上方側の数值解析結果と実 験結果の $\mathrm{CO}_{2}$ のモル濃度の差が土槽下方向より大きくな った。図-12に示すように，圧力差 $0.878 \mathrm{kPa} の$ 場合の $\mathrm{X}=35 \mathrm{~cm}$ の位置についても, 土槽上方向の数值解析結果 の $\mathrm{CO}_{2}$ のモル濃度が実験結果の $\mathrm{CO}_{2}$ のモル濃度より最大 

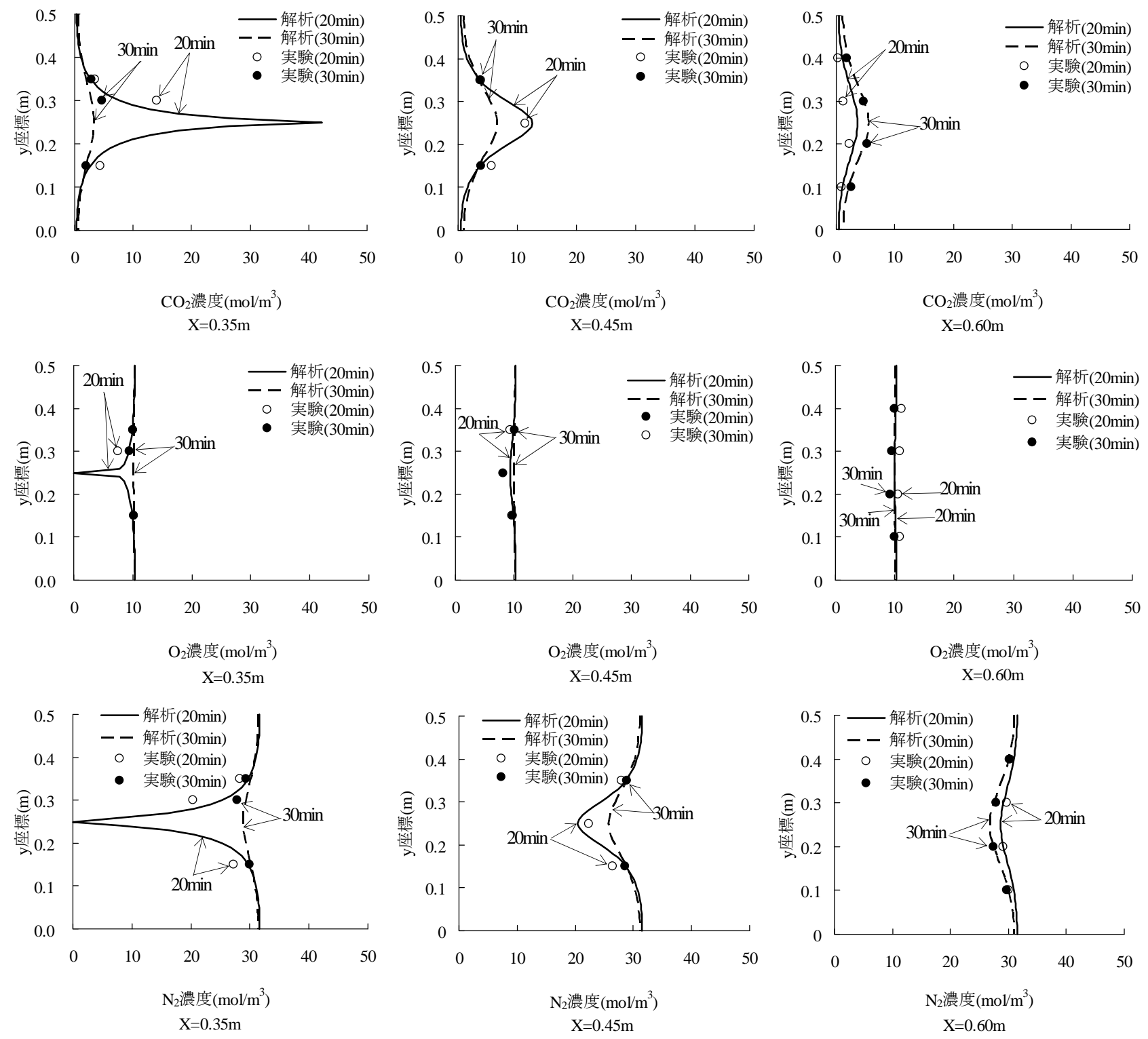

図-11 $X=35 \mathrm{~cm}, 45 \mathrm{~cm}$ と $60 \mathrm{~cm}$ における各成分の濃度分布（豊浦砂+ベントナイト，圧力差 $0.473 \mathrm{kPa}$ ）

$5 \mathrm{~mol} / \mathrm{m}^{3}$ 小さくなったが, 土槽下方での数值解析結果と 実験結果の $\mathrm{CO}_{2}$ のル濃度の分布はほぼ一致した．豊浦 砂の場合と同様，豊浦砂+ベントナイトの場合について も $\mathrm{CO}_{2}$ 注入終了後 10 分（実験開始後30分）の数值解析結 果と実験結果の $\mathrm{CO}_{2}$ の濃度分布の差は, $\mathrm{CO}_{2}$ 注入時（実 験開始後20分）よりも小さくなった.

図-9〜図-12に示すように，数值解析結果の $\mathrm{O}_{2}$ および $\mathrm{N}_{2}$ のモル濃度の分布は実験結果とほぼ一致する。しかし， 数值解析結果と実験結果の $\mathrm{CO}_{2}$ のル濃度が若干相違し ている箇所では，数值解析結果と実験結果の $\mathrm{N}_{2}$ のル濃 度の差が, 数值解析結果と実験結果の $\mathrm{CO}_{2}$ のル濃度の 差と同じ程度となった。模擬空気では $\mathrm{O}_{2}$ 濃度よりも $\mathrm{N}_{2}$ の濃度の方が多いために, $\mathrm{CO}_{2}$ の濃度のずれが $\mathrm{N}_{2}$ の濃度

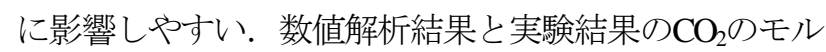
濃度のずれが生じているところでは， $\mathrm{N}_{2}$ の数值解析結果
と実験結果のモル濃度のずれも生じたとが考えられる.

図-5と図-6で $\mathrm{CO}_{2}$ のモル濃度 $2 \mathrm{~mol} / \mathrm{m}^{3}$ の分布位置がずれ いた箇所でも，図-9〜図-12によると豊浦砂の場合の数 值解析結果の $\mathrm{CO}_{2}$ と $\mathrm{N}_{2}$ のモル濃度は, 最大で $2 \mathrm{~mol} / \mathrm{m}^{3}$ 程度 実験結果と差が生じた。一方, 豊浦砂+ベントナイトに ついては, 数值解析結果の $\mathrm{CO}_{2}$ と $\mathrm{N}_{2}$ のモル濃度が，一部 で, 実験結果と5 $6 \mathrm{~mol} / \mathrm{m}^{3}$ 程度の差が生じたが，大半で 実験結果と一致した. また, 実駼結果と数值解析結果の $\mathrm{O}_{2}$ のモル濃度はどのケースについてもほぼ一致した。し かし, 今回の解析では, 土槽排出側口の境界条件が不適 切であり，また，実験結果についても地盤内が一様な流 れになっていなかった可能性がある.

以上のことより, 数值解析結果と実験結果の各成分の モル濃度はほぼ一致したと考えられるため, 日比と 田口 ${ }^{15)}$ が開発した手法で求められた, 屈曲度を考慮し 

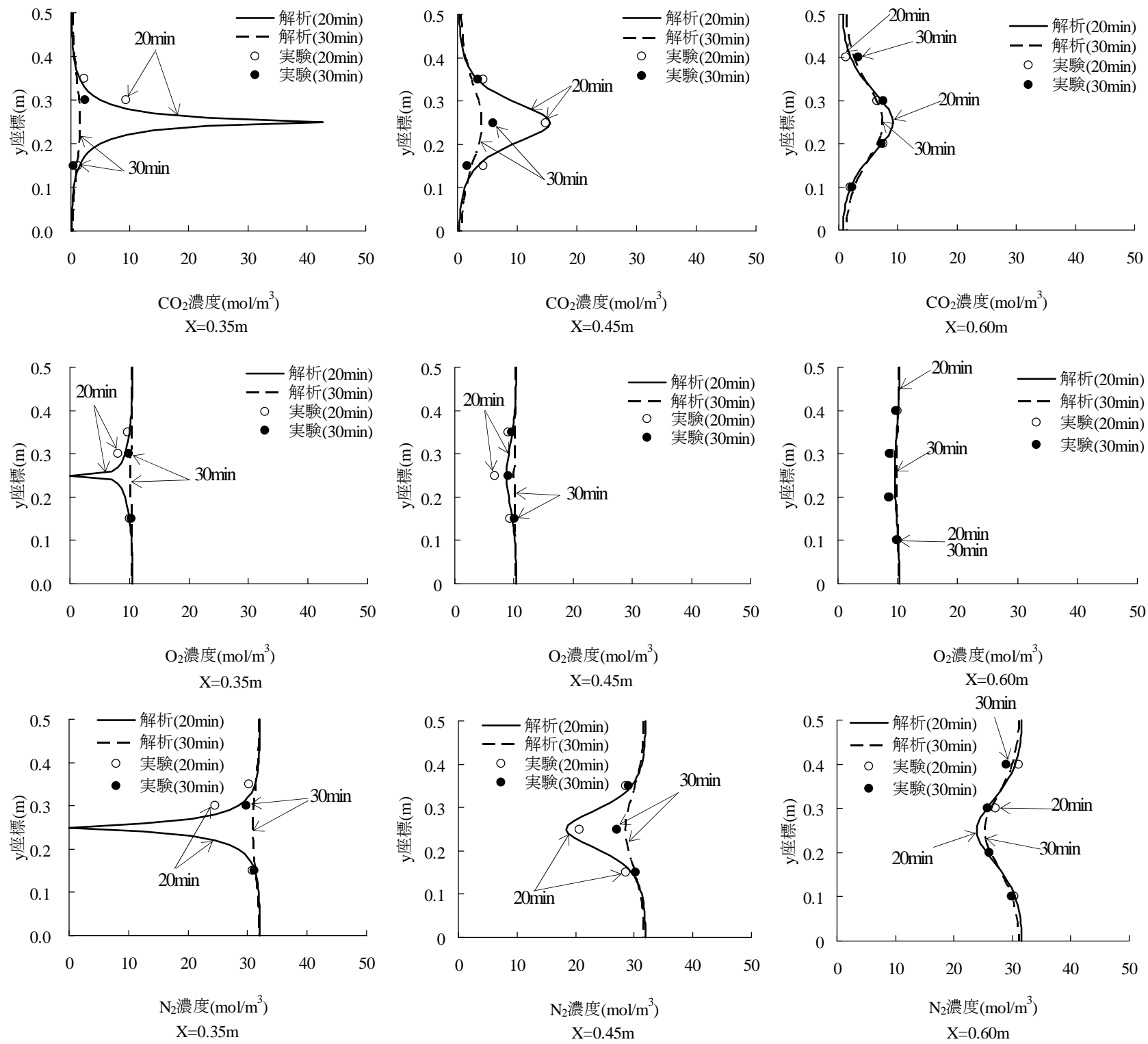

図-12 X=35cm, 45cm と $60 \mathrm{~cm}$ における各成分の濃度分布図（豊浦砂+ベントナイト，圧力差 0.878 $\mathrm{kPa}$ )

た分子拡散係数とKnudsen拡散係数および分散長は，同 レベルのスケールであれば，二次元問題に適用できるこ とが分かった。

\section{5. まとめ}

本実験では，一次元カラム実験結果を用いる手法によ り求められた，屈曲度を考慮した分子拡散係数と Knudsen拡散係数および分散長の各パラメーターの值の 妥当性を確認するために，二次元土槽実験とこれのパラ メーターを用いた数值解析を行った．その結果，豊浦砂 の場合はほぼ実験結果と数值解析結果の各ガス成分のモ ル濃度は一致した。一方，豊浦砂+ベントナイトの場合 には，ベントナイトが豊浦砂に均一に混ざらず，二次元
土槽装置内に均一に詰められなかった可能性があり，実 験結果において土槽上方向と下方向への $\mathrm{CO}_{2}$ の侵入の形 態に若干差が生じた可能性がある。このような原因で数 值解析結果と実験結果の $\mathrm{CO}_{2}$ と $\mathrm{N}_{2}$ のモル濃度の分布に若 干の差が生じたが，概ね両者は一致したと考えられる. 従って, 一次元カラム実験により求められた, 屈曲度を 考慮した拡散係数とKnudsen拡散係数および分散長が妥 当な值であることが分かった.

以上のように，日比と田口点がカラム実験より得た屈 曲度を考慮した拡散係数とKnudsen拡散係数および分散 長は，良く二次元土槽実験結果を表現することができた. しかし，今回の実験は微視的分散の範囲での検証である ので，今度，現場でのトレーサ一試験などを用いて巨視 的分散のスケールにおいても適用可能か検証する必要性 がある．また，異なる土質試料およびガスの組み合わせ 
についてこれらのパラメーターを求め，この手法の適用 性についても二次元土槽実験および数值解析などを用い て検証する必要性がある。

謝辞：本研究は平成22年度文部科学省科学研究費補助金 基盤研究(C)(研究代表者：日比義彦，課題番号21560525) の援助の下に実施された。 ここに記して謝意を表す.

\section{参考文献}

1) Bekins, B. A., Cozzarelli, I. M., Godsy, E. M., Warren, E., Essaid, H. I. and Tuccillo, M. E.: Progression of natural attenuation processes at a crude oil spill II: Controls on spatial distribution of microbial populations, Journal Contamination Hydrology, Vol.53, pp.387-406, 2001.

2) Amos, R. T., Mayer, K. U., Beins, B. A., Delin, G. N. and Williams, R. L.: Use of dissolved and vapor-phase gases to investigate methanogenic degradation of petroleum hydrocarbon contamination in the subsurface, Water Resources Research, Vol.41, W02001, pp.1-15, 2005.

3) Fitts, C. R. : Groundwater Science, Academic Press, pp. 343-359, 2002.

4) Jellai, S., Benremita, H., Muntzer, P., Razakarisoa, O. and Schader, G.: A large-scale experiment on mass transfer of trichloroethylene from the unsaturated zone of a sandy aquifer to its interfaces, Journal of Contaminant Hydrology, Vol. 60, pp. 31-53, 2003.

5) Knesfsey, T. J. and Hunt, J. R.: Non-aqueous phase liquid spreading during soil vapor extraction, Journal of Contaminant Hydrology, Vol. 68, pp. 143-164, 2004.

6) Costanza-Robison, M. S. and Brusseau, M. L.: Gas phase advection and dispersion in unsaturated porous media, $\mathrm{Wa}$ ter Resources Research, Vol.38, No.4, pp.7-1-7-10, 2002.

7) Curtiss, C. F. and Hirschfelder, J. O.: Transport properties of multicomponent gas mixture, Journal of Chemical Physics, Vol.17, pp.550-555, 1949.

8) Cunningham, R. E. and Williams, R. J. J.: Diffusion in Gases and Porous Media, Plenum Press, pp.1-80, 1980.

9) Mason, E. A.: Flow and diffusion of gases in porous media,
Journal of Chemical Physics, Vol.46, pp.3199-3216, 1967.

10) Mason, E. A. and Malinauskas, A. P.: Gas Transport in Porous Media: The Dusty Gas Model, Elsevier, pp.30-49, 1983.

11) Thorstenson, D. C. and Pollock, D. W.: Gas transport in unsaturated zones: Multicomponent system and the adequacy of Fick's Laws, Water Resources Research, Vol.23, No.3, pp.477-507, 1989.

12) Massmann, J. and Farrier, D. F.: Effects of atmospheric pressures on gas transport in the vadose zone, Water Resources Research, Vol.28, No.3, pp.777-791, 1992.

13) Abu-Ei-Sha'r, W. and Abriola, L. M.: Experimental assessment of gas transport mechanisms in natural porous media: Parameter evaluation, Water Resources Research, Vol.33, No.4, pp.505-516, 1997.

14) Hibi, Y., Fujinawa, K., Nishizaki, S., Okamura, K. and Tasaki, M.: Investigation for necessity of dispersivity and tortuosity in the Dusty Gas model for a binary gas system in soil, Soils and Foundations, Vol. 50, No.1, pp.143-159, 2010.

15）日比義彦, 田口和弘：Dusty gas モデルを用いた分散 係数之 Knudsen 拡散係数の算出方法の開発, 土木学 会論文集 C, Vol.67, No.2, pp.198-204, 2011.

16) Hibi, Y., Fujinawa, K., Nishizaki, S., Okamura, K. and Tasaki, M.: Multi-component migration in gas phase of soil: Comparison between results of experiments and simulation by Dusty Gas Model, Soils and Foundations, Vol.49, No.4, pp. 569-581, 2009.

17) 日比義彦, 中田周佑, 杉山秋博 : 多孔体中の空気-水NAPL3 相状態における NAPL の残留飽和度の影響評 価，土木学会論文集 C, Vol.66, No.2, pp.418-429, 2010.

18) Fujinawa, K.: A characteristic finite element scheme for convective-dispersion transport with non-equilibrium reaction, International Journal Numerical Methods Engineer, Vol.23, pp.1161-1178, 1986.

19) Poling, B. E., Prausnitz, J. M. and O’Connell, J. P.: The Properties of Gases and Liquids, McGraw-Hill, pp.11.1911.20, 2001.

(2011. 4. 14 受付)

\section{VALUATION OF PARAMETERS FOR THE MIGRATION OF COMPONENTS IN THE GAS SYSTEM OBTAINED BY USING COLUMN EXPERIMENTS}

\section{Yuki KANOU, Yoshihiko HIBI and Yuki OHIRA}

Parameters for the migration of components in the gas system become molecular diffusion and Knudsen diffusion with tortuosity and dipersivity. Hibi et al. developed the method for obtaining these parameters by using column experiments in the previous study. Tank experiments and numerical simulation were conducted in the present study for verifying that values obtained by using the column experiments were adequate. Carbon dioxide was injected into the tank filled dry Toyoura sand or soil mixed Toyoura sand with bentonite, in where these parameter were obtained, and gas adjusting components of oxygen and nitrogen. The numerical simulation was carried out by using the simulator with Dusty gas model and characteristic finite element scheme and by employing the parameters obtained by the column experiments in the previous study. Therefore it was found in this study that these parameters were adequate. 